\section{Zika Virus Infection in the Central Nervous System and Female Genital Tract}

\section{Emanuele Nicastri, Concetta Castilletti, Pietro Balestra, Simonetta Galgani, Giuseppe Ippolito}

Author affiliations: National Institute for Infectious Diseases Lazzaro Spallanzani, Rome, Italy (E. Nicastri, C. Castilletti, P. Balestra, G. Ippolito); Azienda Ospedaliera San

Camillo-Forlanini, Rome (S. Galgani)

DOI: http://dx.doi.org/10.3201/eid2212.161280

To the Editor: On April 9, 2016, a 32-year-old woman from Italy traveled to Santo Domingo in the Dominican Republic. She worked as a volunteer nurse in the outpatient clinic of a primary school of a nongovernmental organization based in Italy. She returned to Italy on April 17. She did not have sexual intercourse during her stay abroad.
On April 26, she was referred to the travel clinic of the National Institute for Infectious Diseases Lazzaro Spallanzani in Rome for a febrile syndrome with rash, generalized headache, and weakness, which started on April 21. Approximately 24 hours later, she was admitted to the institute's medical facility for a suspected neurologic involvement. At admission, she had abnormal gait, strong asthenia, and a disseminated pruritic rash on her face, abdomen, chest, and arms, but she did not have a fever.

During physical examination, the patient was alert and fully oriented. Temperature was $36.9^{\circ} \mathrm{C}$, pulse rate 90 beats/min, blood pressure $100 / 60 \mathrm{~mm} \mathrm{Hg}$, and respiratory rate 20 breaths $/ \mathrm{min}$. She had a diffuse erythematous macular rash and bilateral nonpurulent conjunctival hyperemia without meningeal signs. Findings of a neurologic examination of the upper limbs were within reference ranges.. Muscular strength was reduced in both legs (left > right), whereas tendon reflexes and all sensory modalities were within reference ranges. Results of a contrast-enhanced magnetic resonance imaging of the brain and spinal cord (on day 7), nerve conduction studies

\title{
etymologia
}

\section{Usutu [0o-soo'too] virus}

U sutu virus, named for the Usutu River in Swaziland, is a mosquitoborne flavivirus closely related to Japanese encephalitis virus, West Nile virus, Murray Valley encephalitis virus, and St. Louis encephalitis virus. Usutu virus was first isolated in 1959 from Culex neavei mosquitoes in South Africa. The first recognized infection in a human was in an African man with fever and rash in 1959 but was not reported until 1981

In 2001, Usutu virus emerged in Europe, when it was identified as the etiologic agent of bird - mainly blackbird - mortality. Retrospective analysis of archived tissue samples from wild bird deaths in the Tuscany region of Italy in 1996, however, revealed an earlier introduction of the virus to Europe. It was not thought to be associated with severe or fatal disease in humans until a neuroinvasive infection was reported to have occurred in an Italian woman in 2009.



\section{Sources}

1. Ashraf U, Ye J, Ruan X, Wan S, Zhu B, Cao S. Usutu virus: an emerging flavivirus in Europe. Viruses. 2015;7:219-38. http://dx.doi.org/10.3390/v7010219

2. Pecorari M, Longo G, Gennari W, Grottola A, Sabbatini A, Tagliazucchi S, et al. First human case of Usutu virus neuroinvasive infection, Italy, August-September 2009. Euro Surveill. 2009;14:19446.
3. Weissenböck H, Bakonyi T, Rossi G, Mani P, Nowotny N. Usutu virus, Italy, 1996. Emerg Infect Dis. 2013;19:274-7. http://dx.doi.org/10.3201/eid1902.121191

4. Weissenböck H, Kolodziejek J, Url A, Lussy H, Rebel-Bauder B, Nowotny N. Emergence of Usutu virus, an African mosquito-borne flavivirus of the Japanese encephalitis virus group, central Europe. Emerg Infect Dis. 2002;8:652-6. http://dx.doi.org/10.3201/eid0807.020094

Address for correspondence: Ronnie Henry, Centers for Disease Control and Prevention, 1600 Clifton Rd NE, Mailstop E03, Atlanta, GA 30329-4027, USA; email: boq3@cdc.gov

DOI: http://dx.doi.org/10.3201/eid2212.ET2212 
and electromyography (on day 8), and an electroencephalogram (on day 16) were within reference ranges. A lumbar puncture (on day 7) showed normal cell counts $(<10$ cells $/ \mathrm{mL})$, a normal glycorrachia/glycemia ratio $(>0.5)$, and a slight increase in protein concentration $(0.48 \mathrm{~g} / \mathrm{L}$ [reference range $0.32-0.80 \mathrm{~g} / \mathrm{L}$ ] $)$ in cerebrospinal fluid. Complete neuropsychologic examinations (on days 9 and 10) showed mild deficits in attention and mental processing speed and mental flexibility and moderate deficits in verbal and nonverbal memory tasks (online Technical Appendix, http://wwwnc.cdc.gov/EID/ article/22/12/16-1280- Techapp1.pdf).

Real-time reverse transcription PCR (rRT-PCR) results for dengue viruses $1-4$ and chikungunya virus were negative in serum and cerebrospinal fluid (CSF), whereas Zika virus RNA was detected in serum (day 6), urine (up to day 27), CSF (day 7), saliva (up to day 13), and vaginal swab (up to day 13) (online Technical Appendix). Specific dengue and chikungunya IgG and IgM were not detected in serum and CSF. Zika virus IgM was detected in serum starting on day 6. Zika virus-specific antibodies in serum were confirmed by microneutralization assay (Table).

Starting on day 7 , intravenous polyvalent immunoglobulins were administered $(0.4 \mathrm{~g} / \mathrm{kg} /$ day for 5 days $)$; no adverse events were observed. A second neuropsychologic examination was performed on day 16 and indicated persistent impairment in memory performances and an improvement in mental concentration and flexibility tasks (online Technical Appendix).
A second lumbar puncture (on day 17) showed an increased cell count (70 cells $/ \mathrm{mL}$, mostly lymphocytes), and CSF was negative for Zika virus RNA by rRT-PCR. The patient was discharged on day 20 ; she showed a progressive neurologic recovery starting on day 16 . At 60-days follow-up visit, no neurologic deficits were reported.

During the 2013-2014 outbreak of Zika virus in French Polynesia and in the context of the 2015-2016 Zika virus circulation (1), an apparent increase in Guillain-Barré syndrome incidence was reported. Few anecdotal cases of encephalopathy in patients with Zika virus infection have been recently described in affected countries: 1 case in a man on a 4-week cruise through an area in the South Pacific that included New Caledonia, Vanuatu, the Solomon Islands, and New Zealand in 2015 (2); and 2 cases in Martinique (3) in February 2016. Recently, Zika virus has been detected in the genital tract of a virusinfected woman after Zika virus had disappeared from blood and urine (4), and a suspected case of Zika virus by sexual transmission from a woman to a man has been reported in New York City (5).

In our patient, Zika virus RNA was found in different systems, including the central nervous system and the genital tract. Recently, a mouse model of Zika virus infection by vaginal exposure demonstrated that Zika virus replicated within the genital mucosa, persisted postinfection, and was detected in the fetal brain of the mice (6). In our case, the patient reported early neurologic symptoms and moderate memory impairment in neuropsychologic examinations, all

\begin{tabular}{|c|c|c|c|c|c|c|}
\hline Test/specimen type & $\begin{array}{c}\text { 1st sample, } \\
\text { day } 6 \dagger\end{array}$ & $\begin{array}{c}\text { 2nd sample, } \\
\text { day } 7 \dagger\end{array}$ & $\begin{array}{c}\text { 3rd sample, } \\
\text { day } 10 \dagger\end{array}$ & $\begin{array}{c}\text { 4th sample, } \\
\text { day } 13 \dagger\end{array}$ & $\begin{array}{c}\text { 5th sample, } \\
\text { day } 17 \dagger\end{array}$ & $\begin{array}{c}\text { 6th sample, } \\
\text { day } 28 \dagger\end{array}$ \\
\hline \multicolumn{7}{|l|}{ Zika virus } \\
\hline rRT-PCR $\ddagger$ serum & $\begin{array}{c}\text { Positive } \\
(32.9)\end{array}$ & Negative & Negative & Negative & Negative & Negative \\
\hline rRT-PCR $\ddagger$ urine & $\begin{array}{c}\text { Positive } \\
\text { (34.2) }\end{array}$ & $\begin{array}{c}\text { Positive } \\
\text { (31.8) }\end{array}$ & $\begin{array}{c}\text { Positive } \\
\text { (32.4) }\end{array}$ & $\begin{array}{l}\text { Positive } \\
\text { (29.8) }\end{array}$ & $\begin{array}{l}\text { Positive } \\
\text { (32.1) }\end{array}$ & $\begin{array}{l}\text { Positive } \\
\text { (32.2) }\end{array}$ \\
\hline rRT-PCR $\ddagger$ saliva & ND & $\begin{array}{l}\text { Positive } \\
\text { (29.9) }\end{array}$ & $\begin{array}{l}\text { Positive } \\
\text { (33.5) }\end{array}$ & $\begin{array}{l}\text { Positive } \\
\text { (34.1) }\end{array}$ & Negative & Negative \\
\hline rRT-PCR $\ddagger$ CSF & ND & $\begin{array}{l}\text { Positive } \\
\text { (37.0) }\end{array}$ & ND & ND & Negative & ND \\
\hline rRT-PCR $\ddagger$ cervical swab sample & ND & $\begin{array}{l}\text { Positive } \\
\text { (31.1) }\end{array}$ & Negative & $\begin{array}{c}\text { Positive } \\
\text { (34.3) }\end{array}$ & Negative & Negative \\
\hline IFA§ IgM titer & $<1: 20$ & $1: 40$ & $1: 160$ & $1: 80$ & $1: 320$ & $1: 1,280$ \\
\hline IFA§ IgG titer & $<1: 20$ & $<1: 20$ & $1: 40$ & $1: 320$ & $1: 320$ & $1: 320$ \\
\hline MNTT $\mathrm{Ab}$ titer & ND & ND & $1: 40$ & ND & $1: 160$ & $\geq 1: 640$ \\
\hline Dengue virus IFA§ IgM titer & $<1: 20$ & $<1: 20$ & $<1: 20$ & $<1: 20$ & $<1: 20$ & $<1: 20$ \\
\hline Dengue virus IFA§ IgG titer & $<1: 20$ & $<1: 20$ & $<1: 20$ & $<1: 20$ & $<1: 20$ & $<1: 20$ \\
\hline Chikungunya virus IFA§ IgM titer & $<1: 20$ & $<1: 20$ & $<1: 20$ & $<1: 20$ & $<1: 20$ & $<1: 20$ \\
\hline Chikungunya virus IFA§ IgG titer & $<1: 20$ & $<1: 20$ & $<1: 20$ & $<1: 20$ & $<1: 20$ & $<1: 20$ \\
\hline \multicolumn{7}{|c|}{$\begin{array}{l}\text { *Ab, antibody; CSF, cerebrospinal fluid; IFA, immunofluorescence assay; MNT, microneutralization test; ND, not done; rRT-PCR, real-time reverse } \\
\text { transcription PCR. } \\
\text { †Days from symptom onset. } \\
\text { tZika virus-specific rRT-PCR (RealStar Zika Virus RT-PCR Kit 1.0; Altona Diagnostics GmbH; Hamburg, Germany). Numbers in parentheses indicate } \\
\text { cycle threshold values (online Technical Appendix, http://wwwnc.cdc.gov/EID/article/22/12/16-1280-Techapp1.pdf). } \\
\text { §lgG and IgM IFA (Arbovirus Mosaic 2; Euroimmun AG; Luebeck, Germany). Reference values (titer) serum: }<1: 20=\text { negative; } \geq 1: 20=\text { positive (online } \\
\text { Technical Appendix). }\end{array}$} \\
\hline
\end{tabular}


features consistent with the diagnosis of Zika virus-related encephalitis, which represents a rare atypical presentation, particularly in areas to which Zika virus infection is not endemic. A recent article shows that Zika virus can infect adult murine neural stem cells, leading to cell death and reduced proliferation (7). It raises the possibility that Zika is not simply a transient infection in adult humans and that exposure in the adult brain could have an effect on longterm memory or the risk for depression (7).

Our case highlights the potential for Zika virus neurotropism and the need for early identification of Zika virusrelated neurologic symptoms. Moreover, the presence of Zika virus in the genital tract supports the recommendation of safe sex practice for women returning home from areas with ongoing Zika virus transmission.

The study was funded by Ricerca Corrente of the Italian Ministry of Health.

\section{References}

1. European Centre for Disease Prevention and Control. Rapid risk assessment. Zika virus disease epidemic. Sixth update, 20 May 2016. Stockholm: The Centre; 2016 [cited 2016 Aug 1]. http://ecdc.europa.eu/en/publications/Publications/zika\%20 virus\%20rapid\%20risk\%20assessment\%2010-05-2016.pdf
2. Carteaux G, Maquart M, Bedet $\mathrm{A}$, Contou $\mathrm{D}$, Brugières $\mathrm{P}$, Fourati S, et al. Zika virus associated with meningoencephalitis. N Engl J Med. 2016;374:1595-6. http://dx.doi.org/10.1056/ NEJMc1602964

3. Rozé B, Najioullah F, Signate A, Apetse K, Brouste Y, Gourgoudou S, et al. Zika virus detection in cerebrospinal fluid from two patients with encephalopathy, Martinique, February 2016. Euro Surveill. 2016;21:30205. http://dx.doi.org/10.2807/15607917.ES.2016.21.16.30205

4. Prisant N, Bujan L, Benichou H, Hayot P-H, Pavili L, Lurel S, et al. Zika virus in the female genital tract. Lancet Infect Dis. 2016;pii: S1473-3099(16)30193-1. http://dx.doi.org/10.1016/ S1473-3099(16)30193-1

5. Davidson A, Slavinski S, Komoto K, Rakeman J, Weiss D. Suspected female-to-male sexual transmission of Zika virusNew York City, 2016. MMWR Morb Mortal Wkly Rep. 2016;65):716-7. http://dx.doi.org/10.15585/mmwr.mm6528e2

6. Yockey LJ, Varela L, Rakib T, Khoury-Hanold W, Fink SL, Stutz B, et al. Vaginal exposure to Zika virus during pregnancy leads to fetal brain infection. Cell. 2016;166:1247-1256.e4. http://dx.doi.org/10.1016/j.cell.2016.08.004

7. Li H, Saucedo-Cuevas L, Regla-Nava JA, Chai G, Sheets N, Tang W, et al. Zika virus infects neural progenitors in the adult mouse brain and alters proliferation. Cell Stem Cell. 2016;pii:19345909(16)30252-1. http://dx.doi.org/10.1016/j.stem.2016.08.005

Address for correspondence: Concetta Castilletti, National Institute for Infectious Diseases INMI-IRCCS, Via Portuense 292, 00149 Rome, Italy; e-mail: concetta.castilletti@inmi.it

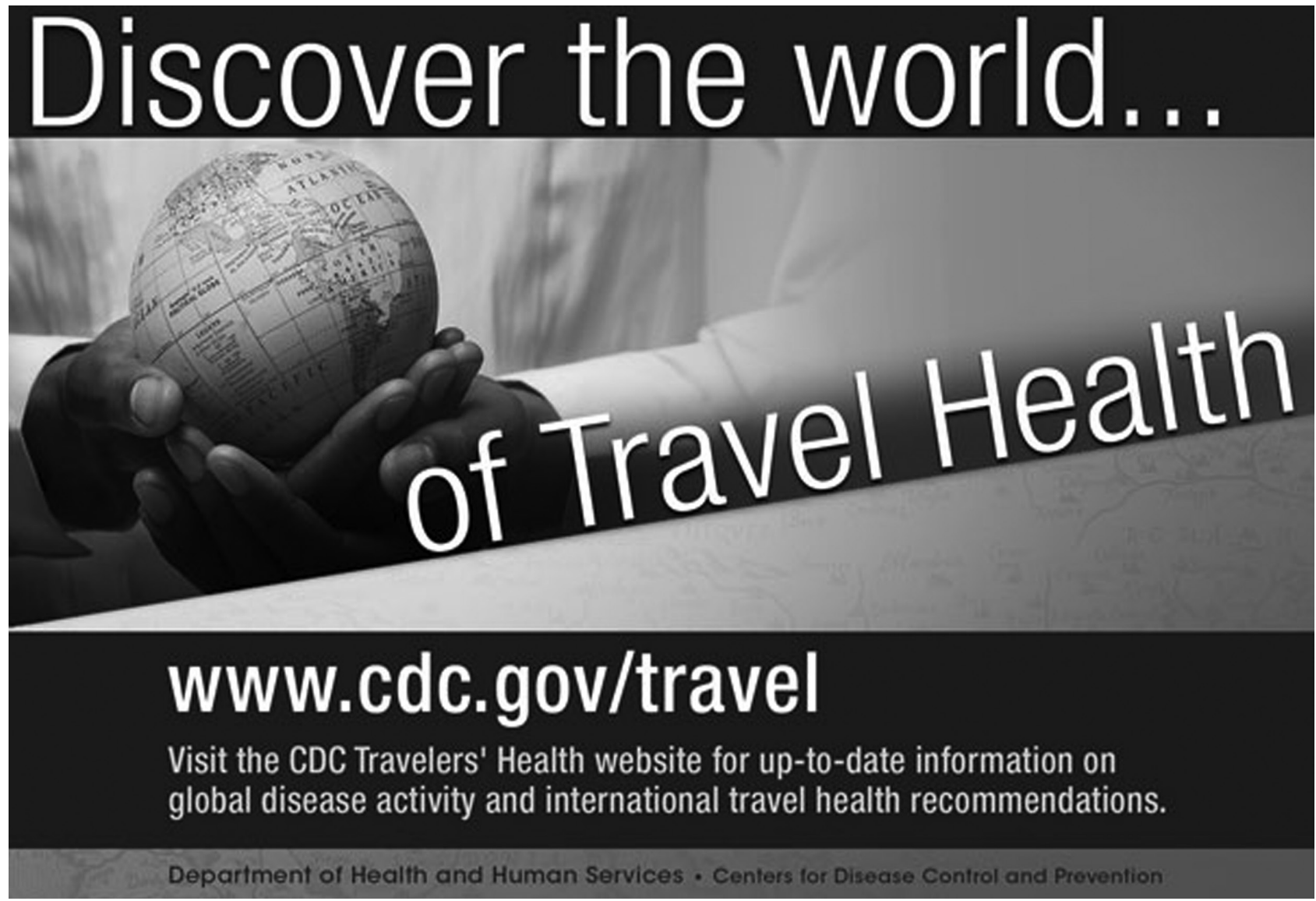

